\section{AB0236 WHAT FACTORS ARE ASSOCIATED WITH THE EVOLUTION TOWARDS RHEUMATOID ARTHRITIS, USE OF BIOLOGICAL THERAPY AND DEVELOPMENT OF CARDIOVASCULAR EVENTS IN A COHORT OF PATIENTS WITH UNDIFFERENTIATED ARTHRITIS?}

Jerusalem Calvo Gutierrez ${ }^{1}$, Rafaela Ortega Castro ${ }^{1}$, Clementina López-Medina ${ }^{2}$, Ladehesa Pineda Lourdes ${ }^{1}$, María del Carmen Castro Villegas ${ }^{1}$, Alejandro Escudero Contreras ${ }^{1}$, Eduardo Collantes Estevez ${ }^{1} .{ }^{1}$ Reina Sofía University Hospital, Maimónides Institute of Biomedical Research of Córdoba (IMIBIC), University of Córdoba, Rheumatology, Cordoba, Spain; ${ }^{2}$ Cochin Hospital, Rheumatology, Paris, France

Objectives: To describe the clinical-demographic characteristics and behaviour over time (12, 24 and 60 months) of a cohort of Undifferentiated Arthritis (UA), as well as to analyze which factors are associated with the evolution towards Rheumatoid Arthritis (RA), use of Biological Therapy (BT) and the development of Cardiovascular Disease (CVD). Methods: Ambispective cohort study of patients with UA evaluated longitudinally from January 2009 to 2019. We analyzed baseline clinical and laboratory variables and a Multivariate Logistic Regression was performed to determine the factors associated with RA development after 5 years of follow-up. To analyze what factors were associated with the use of BT and the presence of CVD chi-square or Fisher's test were used for binary variables, and U-Mann Whitney for continuous variables.

Results: 180 patients were included, $55 \%$ were women, with an average age of 49.3 (SD 16.1) years. The average duration of symptoms before the first visit was 6.9 (SD 9.9) months. $47.2 \%$ were $\mathrm{FR}+, 41 \%$ ACPA+, 20.6\% HLA-DRB1 shared epitope.

At the end of follow-up: $33.3 \%$ evolved to RA, $17.2 \%$ remained as palindromic rheumatism, $25 \%$ were diagnosed other chronic rheumatic diseases, $21.1 \%$ remitted spontaneously and $3.3 \%$ remained as UA. Of the $60 \mathrm{AR}, 37$ were diagnosed in the first year, 13 at second and 10 at 5 years of follow-up. During follow-up, 13 patients with RA started BT, and 12 patients presented CVD (7 of them died).

Table 1:. Factors associated with RA after 5 years of follow-up.

\begin{tabular}{|c|c|c|c|c|c|}
\hline Baseline data & $\begin{array}{c}\text { Total patients } \\
\mathrm{N}=180\end{array}$ & $\begin{array}{c}\mathrm{RA} \\
\mathrm{N}=60\end{array}$ & $\begin{array}{l}\text { No RA } \\
N=120\end{array}$ & OR $(95 \% \mathrm{IC})$ & $\mathrm{p}$-value \\
\hline Sex (women) & $99(45.7 \%)$ & $\begin{array}{c}34 \\
(56.7 \%)\end{array}$ & $\begin{array}{c}65 \\
(54.2 \%)\end{array}$ & $\begin{array}{c}1.11(0.69- \\
2.07)\end{array}$ & 0.751 \\
\hline $\begin{array}{l}\text { Duration of symptoms } \\
\text { (months) }\end{array}$ & $7.7(8.8)$ & $7.5(6.5)$ & $7.8(9.8)$ & $\begin{array}{c}0.99(0.96- \\
1.03)\end{array}$ & 0.864 \\
\hline Age at diagnosis & $49.3(16.1)$ & $\begin{array}{c}49.4 \\
(14.5)\end{array}$ & $\begin{array}{c}49.3 \\
(16.9)\end{array}$ & $\begin{array}{c}1.00(0.98- \\
1.02)\end{array}$ & 0.961 \\
\hline -Oligoarthritis & $84(46.7 \%)$ & 20 & 64 & $2.34(0.49-$ & 0.284 \\
\hline -Polyarthritis & 79 (43.9\%) & $\begin{array}{c}(33.3 \%) \\
38 \\
(63.3 \%)\end{array}$ & $\begin{array}{c}(53.3 \%) \\
41 \\
(34.2 \%)\end{array}$ & $\begin{array}{c}11.14) \\
6.95(1.49- \\
32.42)\end{array}$ & 0.014 \\
\hline Morning stiffness $>1 \mathrm{~h}$ & $43(23.9 \%)$ & $\begin{array}{c}22 \\
(36.7 \%)\end{array}$ & $\begin{array}{c}21 \\
(17.5 \%)\end{array}$ & $\begin{array}{c}2.73(1.35- \\
5.52)\end{array}$ & 0.005 \\
\hline RF+ & $85(47.2 \%)$ & $\begin{array}{c}47 \\
(78.3 \%)\end{array}$ & $\begin{array}{c}38 \\
(31.7 \%)\end{array}$ & $\begin{array}{c}7.8(3.78- \\
16.1)\end{array}$ & $<0.001$ \\
\hline ACPA+ & $73(41.0 \%)$ & $\begin{array}{c}50 \\
(83.3 \%)\end{array}$ & $\begin{array}{c}23 \\
(19.5 \%)\end{array}$ & $\begin{array}{c}20.6(9.1- \\
46.7)\end{array}$ & $<0.001$ \\
\hline High ESR & $104(57.8 \%)$ & $\begin{array}{c}40 \\
(66.7 \%)\end{array}$ & $\begin{array}{c}64 \\
(53.3 \%)\end{array}$ & $\begin{array}{c}1.75(0.92- \\
3.34)\end{array}$ & 0.089 \\
\hline Hight CRP & $100(55.6 \%)$ & $\begin{array}{c}40 \\
(66.7 \%)\end{array}$ & $\begin{array}{c}60 \\
(50 \%)\end{array}$ & $\begin{array}{c}2.0(1.05- \\
3.81)\end{array}$ & 0.035 \\
\hline $\begin{array}{l}\text { HLADRB1 Shared } \\
\text { epitope }\end{array}$ & $37(20.6 \%)$ & $\begin{array}{c}32 \\
(53.3 \%)\end{array}$ & $5(4.2 \%)$ & $\begin{array}{l}26.3(9.39- \\
73.55)\end{array}$ & $<0.001$ \\
\hline Smoker & $72(40 \%)$ & $\begin{array}{c}25 \\
(41.7 \%)\end{array}$ & $\begin{array}{c}47 \\
(39.2 \%)\end{array}$ & $\begin{array}{c}1.11(0.59- \\
2.08)\end{array}$ & 0.747 \\
\hline Family history RA & 39 (21.7\%) & $\begin{array}{c}17 \\
(28.3 \%)\end{array}$ & $\begin{array}{c}22 \\
(18.3 \%)\end{array}$ & $\begin{array}{c}1.76(0.85- \\
3.64)\end{array}$ & 0.127 \\
\hline Tto glucocort $(5 \mathrm{mg} / \mathrm{d})$ & $88(48.9 \%)$ & $\begin{array}{c}40 \\
(66.7 \%)\end{array}$ & $\begin{array}{c}48 \\
(40 \%)\end{array}$ & $\begin{array}{c}3.0(1.57- \\
5.74)\end{array}$ & 0.001 \\
\hline Tto dolquine $(200 \mathrm{mg} / \mathrm{d})$ & $50(27.8 \%)$ & $\begin{array}{c}25 \\
(41.7 \%)\end{array}$ & $\begin{array}{c}25 \\
(20.8 \%)\end{array}$ & $\begin{array}{c}2.71(1.38- \\
5.34)\end{array}$ & 0.004 \\
\hline Tto $\mathrm{mtx}(15 \mathrm{mg} / \mathrm{w})$ & $16(8.9 \%)$ & $\begin{array}{c}14 \\
(23.3 \%)\end{array}$ & $2(1.7 \%)$ & $\begin{array}{l}17.9(3.93- \\
82.12)\end{array}$ & $<0.001$ \\
\hline
\end{tabular}

Table 1 identifies the factors associated with the development of RA The MLR identified ACPA +, OR $(95 \% \mathrm{Cl})=10.69(4.43-25.78)$, and the HLA-DRB1 shared epitope OR $(95 \% \mathrm{Cl})=9.18(2.96-28.48) \mathrm{p}$ $<\mathbf{0 . 0 0 1}$ as factors associated to the development of AR. We failed to identify factors associated with the use of BT, possibly due to the sample size. The factors associated with the development of CVD, where only the use of glucocorticoids as a factor associated with the presence of CVD shows statistical significance.
Conclusion: 1) Useful clinical and laboratory characteristics have been identified to predict which patients are at risk of developing persistent arthritis. 2) HLADRB1 shared Epitope and ACPA are predictive factors of evolution to RA. 3) Possibly the continued use of glucocorticoids, even at low doses, may be related to the development of long-term CVD

Disclosure of Interests: Jerusalem Calvo Gutierrez: None declared, Rafaela Ortega Castro: None declared, Clementina López-Medina: None declared, Ladehesa Pineda Lourdes: None declared, María del Carmen Castro Villegas Paid instructor for: MSD, Abbvie, Pfizer, Janssen, Lilly, Roche, Alejandro Escudero Contreras: None declared, Eduardo Collantes Estevez: None declared DOI: 10.1136/annrheumdis-2019-eular.5030

\section{\begin{tabular}{|l|l} 
AB0237 WHAT DO SPANISH RHEUMATOLOGISTS THINK \\
\hline
\end{tabular} ABOUT THE EFFICACY OF THE DRUGS USED IN THE MANAGEMENT OF PATIENT WITH RHEUMATOID ARTHRITIS AND POOR PROGNOSIS FACTORS? PROGRESAR-2 PROJECT}

Loreto Carmona ${ }^{1}$, J. Narváez ${ }^{2}$, Jaime Calvo ${ }^{3}$, Alejandro Escudero Contreras ${ }^{4}$, Santiago Muñoz Fernandez ${ }^{5}$, José M. Rodríguez-Heredia ${ }^{6}$, Susana RomeroYuste $^{7}$, Paloma Vela Casasempere ${ }^{8}$, Jose Luis Baquero ${ }^{9}$, Sara Lujan Valdés ${ }^{10}$ Juan J. Sancho Jiménez ${ }^{10} .{ }^{1}$ InMusc (Instituto de Salud Musculoesquelética), Madrid, Spain; ${ }^{2}$ Hospital Universitari de Bellvitge, Barcelona, Spain; ${ }^{3}$ Hospital Universitario Araba, Vitoria, Spain; ${ }^{4}$ Hospital Universitario Reina Sofía, Córdoba, Spain; ${ }^{5}$ Hospital Universitario Infanta Sofía. Universidad Europea, Madrid, Spain ${ }^{6}$ Hospital Universitario de Getafe, Madrid, Spain; ${ }^{7}$ Hospitalario Universitario de Pontevedra, Pontevedra, Spain; ${ }^{8}$ Hospital General Universitario de Alicante, Alicante, Spain; ${ }^{9}$ Scientia Salus, Madrid, Spain; ${ }^{10}$ Medical Department, BristolMyers Squibb, Madrid, Spain

Background: Currently, patients with rheumatoid arthritis (RA) have a wide range of treatments available to achieve a good control of the disease and avoid progression. However, some patients, especially those with poor prognostic factors, need to switch drugs to achieve remission or low disease activity. If we can predict the response to a drug, given specific prognostic profiles, we may be able to choose the best drug for individual patients.

Objectives: To assess the degree of confidence of rheumatologists regarding the efficacy of biologic therapies and specific targeted synthetic molecules in patients with RA harbouring poor prognostic factors.

Methods: A Delphi survey was sent to a group of rheumatologists with the aim to capture the perceived efficacy of a group of drugs (antiTNF T-cell co-stimulants, B-cells depletors, anti IL6, and JAK inhibitors) given different poor prognostic factors are present at the onset of the disease These factors were: interstitial lung disease, elevated $\mathrm{HAQ}$, positive rheu matoid factor $(R F)$, presence of anti-citrullinated protein antibody (ACPA), elevated acute phase reactants (APR), and bone erosions observed by simple x-ray/ultrasound. The survey was circulated in two rounds, with feed-back from the first round. The degree of confidence in the efficacy of the therapies for each specific prognostic profile was collected on a Likert scale from 1 to 9 . The mean $(\mathrm{m})$ and standard deviation (SD) were calculated; agreement was considered if SD $\leq 1$ and $80 \%$ of the scores were in one of the three levels (correspondingly it would be agreement on "ineffectiveness", Idquo;neutrality" and "effectiveness").

Table 1:

\begin{tabular}{|c|c|c|c|c|c|}
\hline \multirow[b]{2}{*}{ Prognostic factor } & \multicolumn{5}{|c|}{ Agreement on the efficacy of therapy $m$ (SD) } \\
\hline & AntiTNF & $\begin{array}{l}\text { T-cell co- } \\
\text { stimulants }\end{array}$ & $\begin{array}{l}\text { Depletion of B } \\
\text { cells }\end{array}$ & $\begin{array}{c}\text { Anti IL- } \\
6\end{array}$ & $\begin{array}{c}\text { Jak } \\
\text { inhibitors }\end{array}$ \\
\hline $\begin{array}{l}\text { Interstitial Lung } \\
\text { Disease }\end{array}$ & $2.5(1.5)$ & $8.6(0.7)$ & $7.0(1.4)$ & $\begin{array}{c}6.2 \\
(1.4)\end{array}$ & $5.1(1.6)$ \\
\hline High $\mathrm{HAQ}$ & $8.1(0.7)$ & $7.4(1.0)$ & $7.0(1.0)$ & $\begin{array}{c}8.1 \\
(0.7)\end{array}$ & $7.9(0.9)$ \\
\hline RF positive & $7.7(0.8)$ & $8.1(0.6)$ & $8.3(0.5)$ & $\begin{array}{c}7.8 \\
(0.8)\end{array}$ & $7.6(0.8)$ \\
\hline ACPA positive & $7.8(0.8)$ & $8.6(0.5)$ & $8.2(0.7)$ & $\begin{array}{c}7.5 \\
(0.8)\end{array}$ & $7.4(0.7)$ \\
\hline Elevated APR & $7.9(0.7)$ & $7.2(0.7)$ & $7.0(0.9)$ & $\begin{array}{c}8.7 \\
(0.5)\end{array}$ & $7.9(0.9)$ \\
\hline $\begin{array}{l}\text { Bone erosions by } \\
R x\end{array}$ & $8.1(0.8)$ & $7.9(0.6)$ & $7.3(0.8)$ & $\begin{array}{l}8.2 \\
(0.5)\end{array}$ & $7.8(0.8)$ \\
\hline $\begin{array}{l}\text { Bone erosions by } \\
\text { US }\end{array}$ & $8.2(0.9)$ & $7.9(0.7)$ & $7.3(1.0)$ & $\begin{array}{c}7.9 \\
(0.8)\end{array}$ & $7.8(0.8)$ \\
\hline
\end{tabular}

Conclusion: There is agreement among rheumatologists regarding the behaviour of particular drugs on particular prognostic profiles, except in the case of interstitial pulmonary involvement, $\mathrm{HAQ}, \mathrm{ACPA}+$ and acute 